10. Чому "Євробачення" - це в першу чергу шоу, і чого варто від нього очікувати. Інтерв ю Євгена Філатова. URL: https://vk.com/@eurovision_ua-chomu-vrobachennya-ce-v-pershu-chergu-shou-chogo-varto-vd-nо (дата звернення 18.09.2019).

\title{
References
}

1. Akopjan, K. (2008). Hit-anization, show-anization and exhibitionism in contemporary culture.Ghoryzontu kuljturu: ot massovoj do эlytarnoj. Sankt-Peterburgh. (pp. 15-21). Sankt-Peterburh [in Russian].

2. 2.Dubovyk, Natalyja. (2010). Show-anization of modern culture. V MIST: Mystectvo, istorija, suchasnistj, teorija, 7, 224-233 [in Ukrainian].

3. 3.Eurovision national selection. (data zvernennia 12.09. 2019). Retrieved from: https://uk.wikipedia.org/wiki/.

4. 4.Europeanization. European integration. (data zvernennia 1.09.2019). Retrieved from: https://uk.wikipedia.org/wiki.

5. 5. History of the Eurovision Song Contest. (data zvernennia 12.08.2019). Retrieved from: https://konkursevrov.blogspot.com/.

6. 6.Eurovision Song Contest. (data zvernennia 7.09.2019). Retrieved from: https://uk.wikipedia.org/wiki/.

7. 7.Romanenko Juryj. (data zvernennia 12.09.2019). Show-anization. Proektyvnbj fylosofskyj slovarj: Novbe termynы у ponjatyjaю. Retrieved from: http://ontoimago.spb.nl/article_139.html.

8. 8.Skrypka, Anna. (2010). Show-technology as a form of social communication. Extended abstract of candidate's thesis. Xarkiv [in Ukrainian].

9. 9.Ukraine at the Eurovision Song Contest. (data zvernennia 12.08.2019). Retrieved from: https://uk.wikipedia.org/wiki.

10. Why Eurovision is a show and what is to be expected from it. Interview with Yevgen Filatov. (data zvernennia 18.09.2019). Retrieved from: https://vk.com/@eurovision_ua-chomu-vrobachennya-ce-v-pershu-chergu-shou-chogovarto-vd-no.

Стаття надійшла до редакції 21.11.2019 p. Прийнято до публікації 17.12.2019 р.

УДК 792.82(477)

\author{
Лук'яненко Катерина Аркадіївна \\ аспірантка Київського національного \\ університету культури і мистецтв \\ ORCID 0000-0003-1490-4601 \\ katechoreography@gmail.com
}

\section{УКРАЇНСЬКИЙ БАЛЕТНИЙ ТЕАТР 1960-1970-х рр.: СЦЕНІЧНІ ПРАКТИКИ}

\begin{abstract}
Метою статті $є$ визначення тенденцій реформування балетного мистецтва в 1960-1970-ті рр. та охарактеризувати процеси оновлення у вітчизняному балетному театрі. Методологія дослідження базується на поєднанні історичних, філософських, естетичних, культурологічних та мистецтвознавчих аспектів сучасного наукового пізнання. Застосовано загальнонаукові та конкретно-наукові методи (аналітичний, культурологічний, проблемнохронологічний, типологічний, мистецтвознавчий та теоретичного узагальнення). Наукова новизна. Розглянуто художню концепцію українського балетного театру, як синтез видів мистецтва та ідеї створення художньо-цілісної постановки. У даному контексті акцентовано на процесі формування естетичних ідей балетного театру в Україні як феномену, розвиток та оновлення якого відбувалися під впливом нових суспільних, історичних, культурномистецьких реалій та використання зарубіжного хореографічного та сценічного досвіду. Виявлено тенденції реформування балетного театру в Україні 1960-1970-х рр.; простежено еволюціонування виражальних засобів хореографії протягом означеного періоду та проаналізовано їх вплив на мову та форму балетної вистави. Висновки. Еволюціонування нових засобів виразності балетного театру в Україні в 1960-1970-ті рр. значно посприяло розширенню та поглибленню образної сфери вітчизняного хореографічного мистецтва, що відобразилося передусім на домінуванні у виставах провідних балетмейстерів-постановників найтонших психологічних нюансів та відтінків, проникненні вглиб предмету, майстерному відображенні дійсності та філософських ідей. Українські балетмейстери-постановники змінюють власне, частково «заангажоване» ставлення до руху, позбавляючись у сміливих експериментальних постановках канонів та заданих форм, в творчих пошуках власного стилю та мови. Проте, не зважаючи на тяжіння постановників до абстрактності та мінімалізму, все ж у балетних виставах українських оперних театрів зберігається програмність та сценарна основа.

Ключові слова: балетний театр, хореографрічне мистецтво, зарубіжні сценічні практики, творчі експерименти, новаторські виражальні засоби. и искусств

Лукьяненко Екатерина Аркадьевна, аспирантка Киевского национального университета культуры

Украинский балетный театр 1960-1970-х гг .: сценические практики

Целью статьи является определение тенденций реформирования балетного искусства в 1960-1970-е гг. и характеристика процессов обновления в отечественном балетном театре. Методология исследования базируется на сочетании исторических, философских, эстетических, культурологических и искусствоведческих аспектов современного научного познания. Применены общенаучные и конкретно-научные методы (аналитический, куль-
\end{abstract}

(C) Лук'яненко К. А., 2020 
турологический, проблемно-хронологический, типологический, искусствоведческий и теоретического обобщения). Научная новизна. Рассмотрена художественная концепция украинского балетного театра, как синтез видов искусства и идеи создания художественно-целостной постановки. В данном контексте акцентировано на процессе формирования эстетических идей балетного театра в Украине как феномена, развитие и обновление которого происходили под влиянием новых общественных, исторических, культурных реалий и использования зарубежного хореографического и сценического опыта. Выявлены тенденции реформирования балетного театра в Украине 1960-1970-х гг.; прослежено эволюционирования выразительных средств хореографии в течение определенного периода и проанализировано их влияние на язык и форму балетного спектакля. Выводы. Эволюционирование новых средств выразительности балетного театра в Украине в 1960-1970-е гг. значительно поспособствовало расширению и углублению образной сферы отечественного хореографического искусства, что отразилось прежде всего на доминировании в спектаклях ведущих балетмейстеров-постановщиков тончайших психологических нюансов и оттенков, проникновении вглубь предмета, мастерском отображении действительности и философрских идей. Украинские балетмейстеры-постановщики постепенно меняют собственное «заангажированное» отношение к движению, избавляясь в смелых экспериментальных постановках канонов и заданных форм, в творческих поисках собственного стиля и языка. Однако, несмотря на стремление постановщиков к абстрактности и минимализму, все же в балетных спектаклях украинских оперных театров сохраняется программность и сценарная основа.

Ключевые слова: балетный театр, хореографическое искусство, зарубежные сценические практики, творческие эксперименты, новаторские выразительные средства.

\section{Lukyanenko Kateryna, graduate student, Kiev National University of Culture and Arts, Kiev, Ukraine} Ukrainian Ballet Theater of the 1960s - 1970s: Stage Practices

The purpose of the article is to identify trends in the reform of ballet art in the 1960-1970s. and characterization of renewal processes in the domestic ballet theater. The methodology is based on a combination of historical, philosophical, aesthetic, cultural and art history aspects of modern scientific knowledge. General scientific and concrete scientific methods were applied (analytical, culturological, problem-chronological, typological, art history and theoretical generalization). Scientific novelty. The artistic concept of the Ukrainian ballet theater is considered, as a synthesis of art forms and the idea of creating an artistic and integral production. In this context, it focuses on the process of forming the aesthetic ideas of ballet theater in Ukraine as a phenomenon, the development and updating of which took place under the influence of new social, historical, cultural realities and the use of foreign choreographic and stage experience. The tendencies of reforming the ballet theater in Ukraine of the 1960-1970s are revealed; the evolution of the expressive means of choreography is traced over a certain period and their influence on the language and form of the ballet performance is analyzed. Conclusions. The evolution of new means of expressiveness of the ballet theater in Ukraine in the 1960-1970s. significantly contributed to the expansion and deepening of the figurative sphere of domestic choreographic art, which was reflected primarily in the dominance in the performances of the leading choreographers of the subtlest psychological nuances and shades, penetration deep into the subject, the masterful reflection of reality and philosophical ideas. Ukrainian choreographers are gradually changing their own "biased" attitude to the movement, getting rid of bold experimental productions of canons and given forms, in the creative search for their own style and language. However, despite the directors' desire for abstractness and minimalism, nevertheless, the programmatic and screenplay basis is preserved in the ballet performances of Ukrainian opera houses. sive means.

Key words: ballet theater, choreographic art, foreign stage practices, creative experiments, innovative expres-

Вступ. Найкращі вистави балетмейстерів у 1960-1970-ті рр. засвідчили зміну вектору режисерського мислення. Поява на сценах балетів-симфоній та їх масштабна популяризація стали приводом для посилення уваги балетмейстерів-постановників до виразності танцю - різноплановість виконавців, можливість танцювати в різних стилях, напрямах та танцювальних техніках зумовили синтезування елементів відмінних танцювальних систем. Високохудожні вимоги та досягнення майстерності, що були заявлені Ф. Лопуховим у 1920-х рр., стали основою творчого пошуку українських балетмейстерів. До того ж відчутним фактором впливу стала творчість зарубіжних хореографів, що передусім відобразилася на інноваційних виражальних засобах, оригінальності форм та незвичному для реалістичного балетного мистецтва попереднього періоду оновленні костюмів та декорацій. Актуальність статті зумовлена важливістю розширення джерельної бази дослідження вітчизняного балетного мистецтва з метою напрацювання теоретико-методологічних підходів до вивчення балетного театру 60-70-х рр. XX ст. як соціокультурного феномена, що суттєво вплинув на подальше функціонування та розвиток хореографічного мистецтва в Україні.

Метою статті є визначення тенденцій реформування балетного мистецтва в 1960-1970-ті pp. та охарактеризувати процеси оновлення у вітчизняному балетному театрі.

Аналіз досліджень засвідчує неабиякий інтерес вітчизняних мистецтвознавців до проблематики розвитку балетного мистецтва другої половини XX ст. - значний масив наукових праць (О. Сайко, О. Кагадій, Є. Коваленко, О. Плахотнюк, О. Шаповал, А. Король, О. Мерлянова та ін.) присвячено вивченню художньої манери відомих балетмейстерів, особливостей реформування стилю, аналізу сенсових акцентів конкретних балетних творів та історії створення балетних вистав; осмисленню художньої цінності балету та конкретних вистав на сучасному етапі розвитку української культури. Проте специфріка оновлення балетного театру 1960-1970-х рр. лишається недостатньо висвітленою в контексті особливостей впливу зарубіжних сценічних практик. 
Виклад основного матеріалу. Орієнтовно у 1960-1970-х рр. у США та західноєвропейських країнах сформувалися головні напрямки сучасної хореографії, а водночас розпочався процес взаємовпливу та збагачення їх лексикою та прийомами різних танцювальних систем - класичний танець значно розширив кордони. Ю. Рязанова стверджує, що імпульсом для взаємодії балету з сучасною хореографією стала творчість А. Алонсо, М. Бежара, Дж. Баланчина, Дж. Роббінса, К. Макміллана, Е. Тюдора, Р. Петі та ін. балетмейстерів, які прагнули створити сучасний класичний танець [7, 20].

На думку Р. Володченкова, зарубіжний балет сприймався радянськими хореографами порізному, а іноді досить неоднозначно, через незвичні принципи, прийоми, школи та напрямки, а головне - іншу систему художніх цінностей [2, 18-19].

У контексті оновлення українського балетного театру означеного періоду, ці події відіграли безпосереднє значення, оскільки взаємні гастролі вітчизняних, американських та європейських труп посприяли можливості побачити, творчо переосмислити та інтегрувати у балетні постановки інноваційні для хореографічної культури СРСР елементи, рішення та ідеї, що кардинально змінило вектор розвитку радянського балетного мистецтва загалом та в Україні зокрема.

Творче зіткнення з новим для радянських балетмейстерів баченням хореографічного мистецтва, посприяло переосмисленню ситуації у вітчизняному балетному театрі, що в першу чергу відобразилося на руйнуванні консервативних поглядів та заклало початок взаємовпливу зарубіжного та радянського балетів.

Беззаперечним є вплив на українських балетмейстерів вистав трупи «New-York City Ballet» Дж. Баланчина, в яких класичний танець був головним виражальним засобом, а принцип симфонічного балету Ф. Лопухова реалізовувався на американському грунті. Вистави трупи Дж. Баланчина вирізнялися демонстрацією нових можливостей класичного танцю, а головне - нових приймів розкриття танцювальної образності, що надзвичайно посприяло становленню творчих ідей українських балетмейстерів.

Прикладом новаторського способу мислення балетмейстера та унікальних можливостей пластичної виразності стала вистава Х. Лімона «Павана мавра» (на основі п'єси У. Шекспіра «Отелло»), а власне асоціативний одноактний балет, в якому поєднано засоби класичного танцю та танцю-модерн.

Неабиякий вплив здійснили і вистави режисера та хореографа, французького танцюриста, балетмейстера, драматичного та оперного режисера М. Бежара, що збагатили світовий балет шляхом впливу на розвиток хореографічних засобів та сублімування різноманітних прийомів таких видів мистецтва як опера, оперета, естрадний спів, джаз, драматичний театр, кіномистецтво, архітектура, живопис, фрламенко, японський театр маріонеток, поезії та явищ культури (зокрема спорту та йоги). «Гуру балету», на основі органічного синтезу вищезгаданих елементів культури і мистецтв, створив власний філософський та демократичний театр.

Аналізуючи трансформації мови балетного театру XX ст., Ю. Рязанова акцентує на тому, що в радянському та західному балетах зміни лексики та форми вистави хоча й відбувалися не одночасно та мали власні характерні особливості, а все ж посприяли фрормуванню засобів виразності, котрими вже наприкінці XX ст. стали користуватися всі балетмейстери [7, 12].

Завдяки можливості опанування зарубіжного досвіду розширення меж класичного танцю, українські балетмейстери також розпочали експериментувати, звертаються до сучасних хореографічних напрямків, як інноваційних джерел оновлення та збагачення традиційної лексики вітчизняного балетного театру, відкриття новаторських прийомів, а головне - нового, нестандартного бачення та осмислення традиційних засобів виразності, що посприяло становленню нестандартних прийомів їх використання.

Л. Маркевич стверджує, що активізація та опанування зарубіжного досвіду на сцені українського балетного театру відбувалися шляхом повторення та інтерпретацій вітчизняними балетмейстерами В. Вронським, М. Заславським, Л. Пантикіним, А. Шекерою та ін. вистав, постановки яких здійснили провідні радянські хореографи. Передусім мова йде про балети, музична партитура яких надавала основу для експериментів заснованих на трансформації визнаної хореографії методом використання підказаних музикою засобів виразності, з метою осучаснення класичної спадщини та розширення репертуару. Дослідниця наводить приклад постановочного рішення В. Вронським балету «Ромео і Джульєтта» С. Прокоф'єва (хореографрія Л. Лавровського) на сцені Київського оперного театру в 1955 р. (виконавці партій головних героїв О. Ковальов та О. Потапова), акцентуючи, що «узагальнююче виразне начало та психологічно-фрілософська багатогранність хореографічного втілення музики» [5, 77] посприяли активізації постановок даного твору в різноманітних авторських інтерпретаціях.

Наприклад, А. Пантикін (Харківський театр опери і балету, 1967 р.; В. Ковтун - Ромео, Т. Кузьміна - Джульєтта) вирішив балетну виставу як ліричну драму характерів (постановник замінив танцювальними епізодами пантомімічні, відмовився від «мальовничої масшабності пластичного рішення» та створив на основі класичного танцю хореографічну лексику, що розкривала усі контрасти музичної драматургії ) [6, 111]; М. Заславський (Львівський оперний театр, 1968 р.; Г. Ісупов - Ромео, $€$. Старікова - Джульєтта) - як своєрідну стилізацію середньовічного способу життя 3 характерним 
для творчості балетмейстера зануренням в емоційно-образний зміст музичної партитури [9]; А. Шекера (Київський оперний театр, 1971 р.) - як фрілософську трагедію.

Унікальна інтерпретація шекспірівського сюжету та музичної партитури С. Прокоф'єва А. Шекерою, виявилася знаковою не лише для творчості балетмейстера, а й для усього українського балетного театру останньої третини XX ст. - талановитому хореографу вдалося розкрити образну природу музики засобами хореографічної виразності, ретельно розробити хореографічний малюнок персонажів, навіть епізодичних [11, 17-18].

Дослідники, аналізуючи епізоди постановок балету Л. Лавровським та А. Шекерою, акцентують на їх новаторському, відмінному вирішенні, що засвідчує своєрідність прочитання та глибоке осягнення постановником ідеї літературного першоджерела, музичної партитури, емоційної побудови головних тем твору. Наприклад, Є. Коваленко зауважує, що в «Танці лицарів» балетмейстер використовує грубі та погрожуючі жести: «піднята рука з віялоподібно розчепіреними пальцями зловіще виростає над головою, ніби означуючи невидиму корону, та різко падає, ніби розчавлюючи ворога» [4, 38], що набагато органічніше відповідає емоційній побудові теми ворожнечі Капулетті та Монтеккі, з характерними розмашистим пунктирним ритмом та важкою ходою басів, аніж «Танець з подушками» Л. Лавровського; драматизм сцен поєдинків балетмейстер суттєво посилює відмовившись від бутафорської зброї, використовуючи виключно пластичні виражальні засоби; динамікою та емоційною насиченістю вирізняються дуети головних героїв у виконанні В. Парсегова та А. Гавриленко - внутрішню єдність закоханих, яку неможливо розірвати $[12,442]$ А. Шекера підкреслює технічними підтримками.

Як стверджує Ю. Станішевський, балетна вистава «Ромео та Джульєтта» в постановці А. Шекери посприяла «утвердженню якісно нових принципів в українському балетмейстерському мистецтві, збагаченню виражальної палітри й естетики столичного колективу і відкриттю молодих виконавських обдарувань» [10, 186].

Головним балетмейстером Донецького театру опери і балету в 1972-1977 рр. була С. Тулуб'єва, яка здійснила постановку першого російського класичного балету «Спляча красуня» П. Чайковського на основі редакції Ю. Григоровича та автора хореографії М. Петіпа - балетмейстера, який орієнтувався на розвиток форм класичного танцю, надаючи перевагу академічному класичному танцю, як в соло так і в кордебалеті (в характерних танцях він поєднував хореографічну лексику народних італійських, французьких, польських, російських та інших танців з лексикою класичного).

Наслідування (в найкращому сенсі слова) новаторських прийомів та методів провідних радянських балетмейстерів 1960-1970-х рр. у діяльності С. Тулуб'євої спостерігаємо в постановках класичних балетних вистав «Лебедине озеро» П. Чайковського (1973р.) - першого симфонічного балету (композитор, використав в музичній партитурі характерну та класичну сюїти, дієвий танець, пантоміму та кордебалетні сцени, відповідно, кожен епізод був своєрідним етапом створення наскрізної музичної дії), а також балетів «Бахчисарайський фронтан» Б. Асаф'єва (1973 р.), «Баядерка» Л. Мінкуса (1975 р.), «Казки Віденського лісу» на музику Й. Штрауса (1977р.), «Моцертіана» на музику П. Чайковського (1977 р.) та балетів сучасних композиторів. Наприклад у 1974 р. С. Тулуб'єва, спираючись на хореографію І. Чернишова (Ленінградський академічний малий театр опери та балету, 1968 р.), здійснює постановку балетної вистави «Антоній і Клеопатра» Е. Лазарєва за мотивами однойменної трагедії У. Шекспіра $[13,126]$.

Інтегруванням елементів сучасної хореографії вирізняється балетна вистави «Муза Поета» В. Доценка та В. Стародубцева (на честь175-річчя з дня народження О. С. Пушкіна), постановку якої С. Тулуб'єва здійснила в співпраці з В. Шкильком.

О. Ущапівська стверджує, що в хореографії останнього були такі сцени як Перше adagio Музи і Поета, «Ліцеїсти», «Цигани» та «Золотий півник», акцентуючи й на специфіці сюжету вистави, що зумовила втілення балетмейстерами різнобарвної хореографічної палітри, до якої увійшли історичні, бальні, російські, циганські та східні танці $[13,126]$.

Беззаперечним $є$ вплив на розвиток прийомів та методів балетного театру в Україні музичного мистецтва - новаторські принципи побудови форми та образності, якими характеризувалися партитури балетів К. Караєва, С. Прокоф'єва, А. Петрова, А. Хачатуряна, Р. Щедріна та інших радянських композиторів, посприяли переосмисленню доцільності застосування стандартних підходів у процесі побудови хореографічного малюнку балетних вистав. На думку Л. Маркевич, мова йде про кристалізацію в танцювальному малюнку вистави елементів художньої мови нового естетичного рівня, що зумовило подальше еволюціонування українського балетного театру в напрямку поліфонізації (балетмейстери Одеського і Дніпропетровського оперних театрів І. Чернишов, Л. Воскресенська) та симфонічної побудови хореографічної драматургії (постановки А. Шекери на сценах Львівського та Київського оперних театрів).

Утім, на нашу думку, вплив зарубіжних хореографів на українських балетмейстерів 1970-х рр. був безпосередній, особливо це стосується творчості молодих постановників. Наприклад, у 1973 р. балетмейстер Г. Майоров у співпраці зі сценографом Ф. Ніродом та диригентом Б. Чистяковим здійснює на сцені Київського театру опери і балету ім. Т.Г. Шевченка постановку одноактного балету «Світанкова поема» на музику В. Косенка в оркеструванні Л. Колодуба (лібрето В. Тимофєєв). 
Критики відгукнулися схвальними рецензіями, порівнюючи балетну виставу, вирішену в стилі героїчного та лірико-патріотичного твору, з неоромантичним балетом М.Фокіна «Шопеніана», акцентуючи на самобутності балетмейстера-експериментатора, який одним із перших українських хореографів-постановників органічно синтезував національний хореографічний фрольклор із елементами романтизму, академізму та експресивного постмодерну, спілкуючись з глядачем «цілком зрозумілою танцювальною мовою, наснаженою щирими і схвильованими людськими емоціями» [15, с. 7].

Т. Павлюк акцентує на впливі в процесі формування творчої особистості Г. Майорова професійної діяльності П. Вірського, з характерною хореографу яскравою театральністю, святковою оптимістичністю та щедрістю балетмейстерської франтазії в створенні національних шедеврів; А. Шекери, який майстерно окреслював барвами танцю психологічно складі людські характери при створенні монументальних полотен; творчих експериментів О. Виноградова, Б. Ейфмана, В. Дебелого та Г. Ковтуна $[6,148]$.

У 1975 р. А. Шекера та Г. Майоров працюють над постановкою балету «В ім'я життя» на музику Д. Шостаковича. У тогочасних періодичних виданнях знаходимо рецензії Л. Філоненко на дану постановку, сповнену героїчним пафосом та драматичною силою [14]. Критик, акцентуючи на традиційній для А. Шекери прихильності класичному танцю та балетному академізму, зауважив, що балетмейстер напрочуд вдало проекспериментував, синтезувавши елементи «перетвореної традиційної класики та експресивного постмодерну», оскільки це посприяло правдивому розкриттю почуттів героїв «засобами незвичної хореографічної мови», майстерно підпорядкованої постановником «поліфонічним структурам симфонічної партитури» [14].

Звернення українських балетмейстерів-постновників до творчості М. Петіпа, як до ініціатора хореографічного симфонізму, також є характерною рисою балетного театру 1970-х рр. Постановочне рішення видатного французького і російського балетмейстера, творця класичного репертуару другої половини XIX ст., стало основою сценічної інтерпретації балету «Раймонда» О. Глазунова в 1974 р. А. Шекерою.

Однією з характерних рис розвитку балетного театру 70-х рр. XX ст. в Україні стає звернення балетмейстерів-постановників до знакових національних балетних вистав, з метою створення власних хореографічних версій та розвитку самобутнього українського балетного театру.

А. Шекера в даному контексті виступає як революціонер, який водночас зберігає та розвиває традиції українського балетного театру складної драматургії.

Яскравим авторським баченням вирізнялася редакція балету «Лілея» - одного з перших творів на національну тематику в репертуарі балетного театру України. Якщо в сценічній версії балету «Лілея», постановником якої на сцені Київського державного академічного театру опери і балету ім. Т. Шевченка був В. Вронський (1956р.), завдяки специфічним режисерським та хореографічним знахідкам урізноманітнено сценічну історію твору (зокрема детально розроблено лейттеми Лілеї та Степана, оригінально вибудувано дуети головних героїв та органічно пов'язано їх із масовими танцювальними композиціями) [1, 66], то нова сценічна редакція, здійснена А. Шекерою в 1976 р. (музична редакція була здійснена диригентом-постановником балетної вистави О. Рябовим) уособлювало прагнення балетмейстера здійснити нове прочитання твору, вирішити «Лілею» як поетичну легенду. Справжнє піднесене кохання Степана і Лілеї стало лінією образності, суцільного танцювального дійства, що проходить наскрізно через виставу. А. Шекера динамізував сюжетний розвиток балету, посилив романтизовану наснаженість та надав діям головних героїв більш виразного психологічного вмотивування.

Дана постановка засвідчує вдалі пошуки майстра в контексті посилення автентичності української класичної хореографії.

Синтезуючи класичну та народну лексику, А. Шекера посилив драматизацію та образну виразність, дієвість режисури вистави та окремих номерів. Мистецтвознавці наголошують на перетворенні балетмейстером суто пантомімічної партії Князя на танцювальну та зміні характеру даного персонажу - у виконанні М. Прядченко та В. Некрасова перед глядачами поставав образ «галантного красеня, який залюбки бере участь у придворних забавах, але не менш жорстоко поводить 3 кріпаками» [3, 102]. У творчості українських балетмейстерів дотримання кращих традицій класичного балету поєднувалося з прагненням перейти за межі його звичних академічних канонів - натхненні найвдалішими взірцями російського (М. Петіпа, Ю. Григорович та ін.) та вітчизняного балетного мистецтва (Г. Березова, В. Вронський та ін.), вони виявилися відкритими для сприйняття та творчого інспірування талановитих пошуків зарубіжних хореографрів.

1970-ті рр. характеризувалися посиленням вже наявних тенденцій балетного театру: новаторські розробки балетмейстери випробовують під час постановок балетів на історичну тематику, творах на сучасні теми, а також створюючи нові редакції класичних балетів; спостерігається уповільнення синтезування класичного та українського народного танцю через нестачу запозичених виразних засобів нових систем, зокрема танцю модерн та джазового танцю (наприклад, балет «Світанкова поема» на музику В. Костенка) та нагальної необхідності розробки нефольклорних підходів у процесі обробки художнього матеріалу, з метою осучаснення знаково-символічної та естетично-образної системи художньої мови балетної вистави на українській сцені. 
Наукова новизна. Розглянуто художню концепцію українського балетного театру, як синтез видів мистецтва та ідеї створення художньо-цілісної постановки. У даному контексті акцентовано на процесі формування естетичних ідей балетного театру в Україні як феномену, розвиток та оновлення якого відбувалися під впливом нових суспільних, історичних, культурно-мистецьких реалій та використання зарубіжного хореографрічного та сценічного досвіду. Виявлено тенденції реформування балетного театру в Україні 1960-1970-х рр.; простежено еволюціонування виражальних засобів хореографрії протягом означеного періоду та проаналізовано їх вплив на мову та форму балетної вистави.

Висновки. Еволюціонування нових засобів виразності балетного театру в Україні в 1960-1970ті рр. значно посприяло розширенню та поглибленню образної сфрери вітчизняного хореографрічного мистецтва, що відобразилося передусім на домінуванні у виставах провідних балетмейстерівпостановників найтонших психологічних нюансів та відтінків, проникненні вглиб предмету, майстерному відображенні дійсності та філософських ідей.

Розвиваючи досвід 1960-1970-х рр., передусім сублімування режисерського досвіду балетмейстерів доби хореографи та пошуку новаторських виражальних засобів, властивих специфічному балетному мистецтву (варіативна розробка рухів, симфонічний розвиток танцю, створення композиційних прийомів та образних рухів для пластичних партій головних героїв балетних вистав, розробка хореографрічної драматургії вистави та ін.), наприкінці 70-х рp. XX ст. українські балетмейстерипостановники поступово змінюють власне, частково «заангажоване» ставлення до руху, позбавляючись у сміливих експериментальних постановках канонів та заданих форм, в творчих пошуках власного стилю та мови. Проте, не зважаючи на тяжіння постановників до абстрактності та мінімалізму, все ж у балетних виставах українських оперних театрів зберігається програмність та сценарна основа.

\section{תimepamypa}

1. Вишотравка Л. І. Творча діяльність Євгенії Єршової в контексті розвитку мистецьких процесів на українській балетній сцені 1940-1960-х років. Українська культура: минуле, сучасне, шляхи розвитку. 2018. Вип. 26. C. $64-68$

2. Володченков Р. Г. Формирование художественных принципов в советском балете 1960-80-х годов (на примере творчества хореографра И. А. Чернышева): авторефрерат дис. канд. искусствоведения : 17.00 .01 / Российский университет театрального искусства - ГИТИС. Москва, 2015. 30 с.

3. Загайкевич М. Балетна Шевченкіана. Українське мистецтвознавство : матеріали, дослідження, рецензії. Вип. 13. Київ, 2013. 184 с.

4. Коваленко Е. И. Анатолий Федорович Шекера - мастер балетного симфонизма и хореографической полифонии. Южно-российский музыкальный альманах. 2016. № 1(22). С. 37-42.

5. Маркевич Л. А. До питання про модернізація художньої мови балетних вистав 60-80 років XX століття. Українська культура: минуле, сучасне, шляхи розвитку. 2018. Вип. 26. С. 75-84.

6. Павлюк Т.С. Українське балетмейстерське мистецтво (II половина XX ст.). Київ : Вид. центр КНУКіМ, 2017. $230 \mathrm{c}$.

7. Рязанова Ю. Ю. Новые средства выразистельности в балетном искусстве XX века (к проблеме соотношения традиции и новаторства) : автореферат дис. канд. искусствоведения : 17.00 .01 / Российская академия театрального искусства (ГИТИС). Москва, 2016. 32 с.

8. Савченко Р. В. Особливості балетмейстерських пошуків українських хореографів другої половини XX століття: творчий метод Анатолія Шекери. Науковий часопис НПУ імені М .П. Драгоманова. Серія 5. Педагогічні науки: реалії та перспективи. 2017. Вип. 59. С. 143-149.

9. Смотрич А. Гімн юності і коханню. Вільна Україна. 1968. 1 лист.

10. Станішевський Ю. Балетний театр Радянської України, 1925-1985: шляхи і проблеми розвитку. Київ : Музична Україна, 1986. 235 с.

11. Станишевский Ю. Проблемы интеграции украинского хореографического искусства в мировое и европейское культурное пространство. Интеграция украинского искусства в европейсое и мировое культурное пространство : материалы Всеукраинской научно-практической конференции. Киев: Киевское училище хореографического искусства, 2005. С. 9-18.

12. Станішевський Ю. О. Національна опера України. Київ : Музична Україна, 2002. 736 с.

13. Ущапівська О. М. Донецький театр опери та балету як територія не відчуженої комунікації. Мистецтвознавчі записки. 2014. Вип. 26. С. 123-130.

14. Філоненко Л. Народна пам'ять. Київська правда. 1979. 27 квіт.

15. Якименко О. Світанкова поема. Ранок. 1975. № 6. С. 7.

\section{References}

1. Vyshotravka, L. I. (2018). Creative activity of Yevgeniya Ershova in the context of the development of artistic processes on the Ukrainian ballet scene of the 1940s-1960s. Ukrainian culture: past, present, ways of development, Issue 26, pp. 64-68 [in Ukrainian].

2. Volodchenkov, R. G. (2015). Formation of artistic principles in the Soviet ballet of the 1960-80s (on the example of the work of the choreographer I. A. Chernyshev). Abstract of Ph.D. dissertation. Moscow : Russian University of Theater Arts - GITIS [in Russian]. [in Ukrainian].

3. Zagaykevich, M. (2013). Shevchenko Ballet. Ukrainian Art Studies: Materials, Research, Reviews, Issue 13

4. Kovalenko, E. I. (2016). Anatoly Fedorovich Sheker - master of ballet symphony and choreographic polyphony. South Russian musical almanac. 2016. No. 1 (22). S. 37-42. [in Russian]. 
5. Markevich, L. A. (2018). To the question of the modernization of the artistic language of ballet performances 60-80 years of the twentieth century. Ukrainian culture: past, present, ways of development, Issue 26, pp. 75-84 [in Ukrainian].

Ukrainian].

6. Pavlyuk, T. S. (2017). Ukrainian Ballet Art (2nd half of the 20th century). Kiev: View. KNUCiM Center [in

7. Ryazanova, Yu. Yu. (2016). New means of expressiveness in the ballet art of the twentieth century (to the problem of correlation of tradition and innovation). Abstract of Ph.D. dissertation. Moscow : Russian Academy of Theater Arts (GITIS) [in Russian].

8. Savchenko, R. V. (2017). Features of the choreographers' searches for Ukrainian choreographers of the second half of the twentieth century: Anatoly Shekera's creative method. Scientific journal of NPU named after MP. Drahomanov, Vol. 59, pp. 143-149 [in Ukrainian].

9. Smotrich, A. (1968). Hymn of youth and love. Free Ukraine [in Ukrainian].

10. Stanishevsky, Yu. (1986). Ballet Theater of Soviet Ukraine, 1925-1985: Ways and Problems of Development. Kyiv: Musical Ukraine [in Ukrainian].

11. Stanishevsky, Yu. (2005). Problems of integration of Ukrainian choreographic art in the world and European cultural space. Integration of Ukrainian art in the European and world cultural space: materials of the All-Ukrainian scientific-practical conference. Kiev: Kiev School of Choreographic Art, pp. 9-18 [in Russian].

12. Stanishevsky, Y. A. (2002). National Opera of Ukraine. Kyiv: Musical Ukraine [in Ukrainian].

13. Ushchapovskaya, O. M. (2014). Donetsk Opera and Ballet Theater as a territory of not alienated communication. Artistic notes, Vol. 26, pp. 123-130 [in Ukrainian].

14. Filonenko, L. (1979). People's memory. Kiev truth. Apr 27 [in Ukrainian].

15. Yakimenko, O. (1975). The dawn poem. Morning, no. 6, p. 7 [in Ukrainian].

Стаття надійшла до редакції 22.10.2019 p. Прийнято до публікації 20.11.2019 р. 